\title{
A comparison of carbon-specific respiration rates in gelatinous and non-gelatinous zooplankton: a search for general rules in zooplankton metabolism
}

\author{
G. Schneider \\ Biologische Anstalt Helgoland; Hafenstr. 46, D-W-2282 List/Sylt, Federal Republic of \\ Germany
}

\begin{abstract}
Using 470 data from the literature the dry weight-specific respiration rates of gelatinous zooplankton (cnidarians, ctenophores and salps) and non-gelatinous zooplankton (mainly crustacea) were converted to carbon-specific values. The resulting carbon-specific respiration rates showed no significant differences between the two groups of zooplankton, indicating similar oxygen requirements per gram of carbon biomass. From this finding, it can be suggested that the differences in the rates of oxygen consumption measured in the two types of zooplankton in the sea can be explained by the carbon biomass ratio between gelatinous and non-gelatinous zooplankton. Furthermore, the low rate of metabolism of gelatinous species compared with that of non-gelatinous animals of the same volume can be attributed predominantly to the relatively low organic matter content in the former. It is recommended that all weight-specific metabolism rates be expressed using carbon as body mass unit (e.g. $\mathrm{mg} \mathrm{O}_{2} \mathrm{gC}^{-1} \mathrm{~d}^{-1}$ ) which enables more accurate comparisons between individuals exhibiting different dry weight/carbon ratioś.
\end{abstract}

\section{INTRODUCTION}

Metabolism studies on gelatinous zooplankton i.e. cnidarians, ctenophores and thaliaceans revealed lower dry weight-specific rates than those in non-gelatinous zooplankton (cf. Ikeda, 1974), suggesting gelatinous species to be idle with respect to metabolism. On the other hand, gelatinous organisms contain only small amounts of organic matter, with carbon ranging between 1 and $32 \%$ of dry weight, whereas carbon makes up 24-67\% of dry weight in crustaceans (Schneider, 1989a). Therefore, the use in comparisons of weight-specific metabolic rates based on dry matter as biomass unit is misleading, since different amounts of metabolizing organic substances are being compared.

Scientists have been aware of this problem for some time. To my knowledge, the first to notice the importance of organic matter as biomass unit for weight-specific rates was Krüger (1968). Discussing respiration rates of some scyphomedusae, he concluded that organic matter-specific rates were similar to those obtained for carbon rich benthic invertebrates, and, more recently, a comparison of carbon-specific ammonia excretion rates revealed ammonia output to be in the same range per $\mathrm{g}$ carbon in both types of zooplankton mentioned above (Schneider, 1990). Today, scientists working with gelatinous species are generally familiar with the differences between dry weight-specific and carbon-specific metabolic rates (cf. Cetta et al., 1986; Larson, 1987a). 
However, this fact is usually only mentioned within the discussion section of actually published results, and, therefore, is obscured by a lot of other aspects. This paper compares the carbon-specific respiration rates of gelatinous and non-gelatinous zooplankton on a broader data basis with a view toward looking for a general rule of metabolism in all zooplankton.

\section{TREATMENT OF DATA}

Data on the respiration rates of zooplankton from the major ocean regions were taken from 19 articles published between 1937 and 1991. Table 1 lists all the investigations used for this compilation, and provides some information on experimental condi-

Table 1. List of studies used for this contribution. Types of organisms investigated: non-gelatinous zooplankton (n); gelatinous zooplankton (g). Experimental temperatures $\left({ }^{\circ} \mathrm{C}\right)$ and duration of incubation (h) are also given

\begin{tabular}{|c|c|c|c|}
\hline Source & Type & $\begin{array}{c}\text { Temperature } \\
\left({ }^{\circ} \mathrm{C}\right)\end{array}$ & $\begin{array}{c}\text { Incubation } \\
\text { time (h) }\end{array}$ \\
\hline \multicolumn{4}{|l|}{ Polar waters } \\
\hline Biggs (1982) & $\mathrm{n}$ & $-1^{\circ}, 10^{\circ}$ & 1 to 4 \\
\hline Ikeda \& Bruce (1986) & $\mathrm{n}, \mathrm{g}$ & $-1.8^{\circ}$ to $-0.8^{\circ}$ & 24 \\
\hline Ikeda \& Mitchell (1982) & $\mathrm{n}, \mathrm{g}$ & $-1.3^{\circ}$ to $-0.8^{\circ}$ & 24 \\
\hline Ikeda \& Skjoldal (1989) & $\mathrm{n}$ & $-0.5^{\circ}$ to $1.1^{\circ}$ & 24 \\
\hline \multicolumn{4}{|c|}{ Boreal and temperate waters } \\
\hline Hirota (1972) & $\mathrm{g}$ & $11.5^{\circ}$ to $13^{\circ}$ & 24 \\
\hline Ikeda (1974) & $\mathrm{n}, \mathrm{g}$ & $4.3^{\circ}$ to $17.5^{\circ}$ & 4 to 24 \\
\hline Kerstan (1977) & g & $13.5^{\circ}$ to $14.5^{\circ}$ & 19 to 28 \\
\hline Kremer (1977) & g & $10.4^{\circ}$ to $24.5^{\circ}$ & 12 to 26 \\
\hline Krüger (1968) & $\mathbf{g}$ & $15^{\circ}$ & not given \\
\hline Larson (1987) & g & $10^{\circ}, 15^{\circ}$ & 1 to 2 \\
\hline Thill (1937) & $\mathbf{g}$ & $13.5^{\circ}$ to $17.5^{\circ}$ & 1 \\
\hline Weisse (1985) & $\mathrm{n}$ & $15^{\circ}$ & 4 to 18 \\
\hline \multicolumn{4}{|c|}{ Subtropical and tropical waters } \\
\hline Biggs (1977) & g & $26^{\circ}$ & 1 to 6 \\
\hline Cetta et al. (1986) & g & $13.5^{\circ}$ to $28.5^{\circ}$ & 1 to 8 \\
\hline Ikeda (1974) & $n, g$ & $19.7^{\circ}$ to $28.5^{\circ}$ & 4 to 24 \\
\hline Kremer (1982) & g & $22^{\circ}$ & 3 to 10 \\
\hline Kremer et al. (1986) & $\mathrm{g}$ & $25^{\circ}$ & 3 to 5 \\
\hline Menzel \& Ryther (1960) & $\mathrm{n}$ & $20^{\circ}$ to $29^{\circ}$ & 3 to 18 \\
\hline Schneider \& Lenz (1991) & $\mathrm{n}$ & $23^{\circ}$ to $26^{\circ}$ & 3 \\
\hline Shushkina \& Pavlova (1973) & $\mathrm{n}$ & $30^{\circ}$ & 4 to 5 \\
\hline
\end{tabular}

tions. Tables 2 and 3 give ranges and units of original measurements. Prior to presentation of carbon-specific respiration rates it is useful to compare dry weight-specific rates of non-gelatinous and gelatinous zooplankton. For this reason, data from 13 publications were converted to $\mathrm{mg} \mathrm{O}_{2} \mathrm{~g} \mathrm{dw}^{-1} \mathrm{~d}^{-1}$ (in the remaining six articles, dry weight values of experimental individuals were not given). Since the experimental temperatures were 
Table 2. Original respiration rates of non-gelatinous zooplankton. dw: dry weight; ww: wet weight; cal.: calories; ind.: individual; dry weight of experimental individuals are given separately in original sources; $n=$ number of data examined; $n^{*}=$ number of measurements

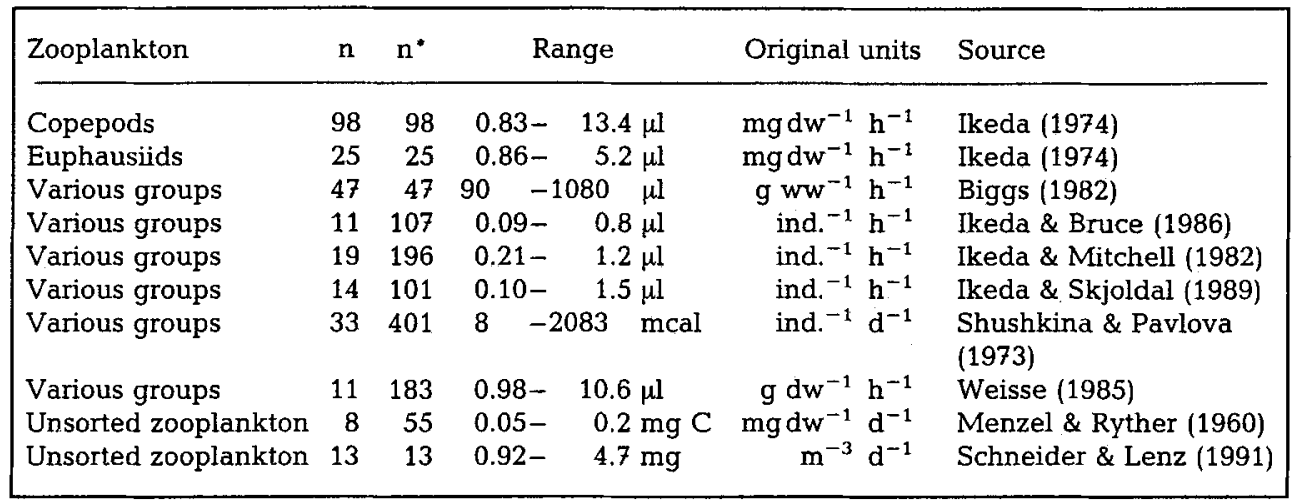

Table 3. Original respiration rates of gelatinous zooplankton. prot.: protein; other symbols as in Table 2

\begin{tabular}{|c|c|c|c|c|c|c|c|}
\hline Zooplankton & $\mathbf{n}$ & $n^{*}$ & & Range & & Original units & Source \\
\hline Scyphomedusae & $\begin{array}{r}4 \\
8 \\
3 \\
4 \\
10\end{array}$ & $\begin{array}{r}7 \\
8 \\
72 \\
67 \\
10\end{array}$ & $\begin{array}{l}3 \\
1.4 \\
7 \\
0.1 \\
0.1\end{array}$ & $\begin{array}{l}-16 \\
-\quad 6.6 \\
-16 \\
-\quad 0.9 \\
-\quad 0.6\end{array}$ & $\begin{array}{l}\mu \mathrm{l} \\
\mu \mathrm{l} \\
\mathrm{mm}^{3} \\
\mu \mathrm{l} \\
\mathrm{ml}\end{array}$ & $\begin{aligned} \text { mg prot. } & h^{-1} \\
\text { ind. } & h^{-1} \\
g ~ w w^{-1} & h^{-1} \\
\text { mg dw } & h^{-1} \\
\text { ind. } & h^{-1}\end{aligned}$ & $\begin{array}{l}\text { Biggs (1977) } \\
\text { Kerstan (1977) } \\
\text { Krüger (1968) } \\
\text { Larson (1987a) } \\
\text { Thill (1937) }\end{array}$ \\
\hline Hydromedusae & $\begin{array}{r}5 \\
8 \\
1 \\
13\end{array}$ & $\begin{array}{r}14 \\
8 \\
8 \\
271\end{array}$ & $\begin{array}{l}7 \\
0.1 \\
0.1\end{array}$ & $\begin{array}{l}-14 \\
-\quad 5.3 \\
2.3 \\
-\quad 0.9\end{array}$ & $\begin{array}{l}\mu \mathrm{l} \\
\mu \mathrm{l} \\
\mu \mathrm{l} \\
\mu \mathrm{l}\end{array}$ & 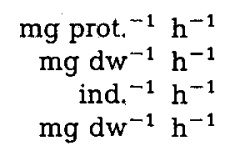 & $\begin{array}{l}\text { Biggs (1977) } \\
\text { Ikeda (1974) } \\
\text { Ikeda \& Skjoldal (1989) } \\
\text { Larson (1987a) }\end{array}$ \\
\hline Siphonophores & $\begin{array}{r}40 \\
4 \\
3\end{array}$ & $\begin{array}{r}222 \\
4 \\
15\end{array}$ & $\begin{array}{l}2.3 \\
0.5 \\
1.5\end{array}$ & $\begin{array}{l}-86 \\
-\quad 0.8 \\
-\quad 5.6\end{array}$ & $\begin{array}{l}\mu l \\
\mu l \\
\mu l\end{array}$ & 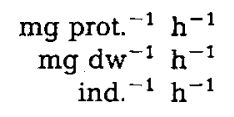 & $\begin{array}{l}\text { Biggs (1977) } \\
\text { Ikeda (1974) } \\
\text { Ikeda \& Bruce (1986) }\end{array}$ \\
\hline Ctenophores & $\begin{array}{l}5 \\
1 \\
3 \\
3 \\
1 \\
6 \\
4 \\
4\end{array}$ & $\begin{array}{r}13 \\
62 \\
3 \\
19 \\
1 \\
144 \\
37 \\
88\end{array}$ & $\begin{array}{c}11 \\
0.1 \\
12 \\
141 \\
6 \\
0.1\end{array}$ & $\begin{array}{l}-23 \\
-\quad 0.3 \\
-\quad 0.4 \\
-41 \\
15 \\
-489 \\
-\quad 29 \\
-\quad 0.4\end{array}$ & $\begin{array}{l}\mu \mathrm{l} \\
\mu \mathrm{l} \\
\mu \mathrm{l} \\
\mu \mathrm{l} \\
\mu \mathrm{l} \\
\mu \mathrm{g}-\mathrm{at} \\
\mu \mathrm{g} \text {-at } \\
\mathrm{mg}\end{array}$ & $\begin{aligned} \text { mg prot. } & h^{-1} \\
\text { mg dw } & h^{-1} \\
\text { mg dw } & h^{-1} \\
\text { ind. } & h^{-1} \\
\text { ind. } & h^{-1} \\
\text { g dw } & \mathrm{d}^{-1} \\
\mathrm{~g} \mathrm{dw}^{-1} & \mathrm{~h}^{-1} \\
\mathrm{~g} \mathrm{dw^{-1 }} & \mathrm{h}^{-1}\end{aligned}$ & $\begin{array}{l}\text { Biggs (1977) } \\
\text { Hirota (1972) } \\
\text { Ikeda (1974) } \\
\text { Ikeda \& Bruce (1986) } \\
\text { Ikeda \& Mitchell (1982) } \\
\text { Kremer (1977) } \\
\text { Kremer (1982) } \\
\text { Kremer et al. (1986) }\end{array}$ \\
\hline Salps & $\begin{array}{r}13 \\
26 \\
15 \\
2 \\
2\end{array}$ & $\begin{array}{r}75 \\
274 \\
15 \\
18 \\
16\end{array}$ & $\begin{array}{l}14 \\
0.003 \\
0.29 \\
50 \\
2.2\end{array}$ & $\begin{array}{l}-192 \\
3-\quad 0.45 \\
-\quad 3.03 \\
-109 \\
-\quad 12\end{array}$ & $\begin{array}{l}\mu \mathrm{l} \\
\mathrm{ml} \\
\mu \mathrm{l} \\
\mu \mathrm{l} \\
\mu \mathrm{l}\end{array}$ & 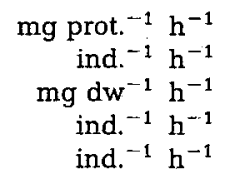 & $\begin{array}{l}\text { Biggs (1977) } \\
\text { Cetta et al. (1986) } \\
\text { Ikeda (1977) } \\
\text { Ikeda \& Bruce (1986) } \\
\text { Ikeda \& Mitchell (1982) }\end{array}$ \\
\hline
\end{tabular}


quite different (Table 1), all the data were standardized to $15^{\circ} \mathrm{C}$ according to the well known $Q_{10}-$ law:

$$
\mathrm{Q}_{10}=(\mathrm{K} 1 / \mathrm{K} 2)^{10 /(\mathrm{t} 1-\mathrm{t} 2)}
$$

where $\mathrm{K} 1$ and $\mathrm{K} 2$ are metabolic rates corresponding to temperatures $\mathrm{t} 1$ and $\mathrm{t} 2$, respectively. A $Q_{10}$ of 2 was used for all data (Ikeda, 1985).

The second step was to convert all the original data from the 20 investigations to $\mathrm{mg}$ $\mathrm{O}_{2} \mathrm{gC}^{-1} \mathrm{~d}^{-1}$. Carbon content was actually measured in only eight studies (Ikeda, 1974; Ikeda \& Mitchell, 1982; Kremer, 1982; Ikeda \& Bruce, 1986; Kremer et al., 1986; Ikeda \& Skjoldal, 1989; Schneider \& Lenz, 1991; and Larson 1987a, who, however, presented the carbon data in Larson, 1986). The obtained values were used for conversions. One exception is the respiration data of salps in Ikeda (1974) since no carbon data for this group are given. Therefore, an average carbon content of $8.1 \%$ of dry weight was assumed (Schneider, 1989a).

For dry weight-specific rates of non-gelatinous zooplankton presented by Menzel \& Ryther (1960) and Weisse (1985), carbon was assumed to contribute $40 \%$ of dry weight (Härdstedt-Roméo, 1982; Schneider, 1989a). For conversion of the caloric values given by Shushkina \& Pavlova (1973), the following factors were applied: $1 \mu \mathrm{l}$ of respired oxygen $=$ $4.86 \mathrm{mcal}$ (Omori \& Ikeda, 1984), and $1 \mu \mathrm{g}$ of carbon biomass $=14.6 \mathrm{mcal}$ (according to Platt et al. [1969] where $\mathrm{C}=40 \%$ of dry weight). In his outstanding work on gelatinous zooplankton, Biggs (1977) presented respiration data using proteins as biomass unit. Since carbon and proteins make up roughly one half of the organic matter each (cf. Raymont, 1983), protein-based respiration rates were considered as equal to the carbonspecific rates. The results for non-gelatinous zooplankton obtained by Biggs (1982) are given per unit of wet weight, and were related to carbon where $C=8 \%$ of wet weight, taking into account that dry weight on average makes up $20 \%$ of wet weight (Omori, 1969) and carbon $40 \%$ of dry weight.

The dry weight to carbon conversion factors for the studies of Krüger (1968), Hirota (1972), Kerstan (1977) and Kremer (1977) were: $C=10.7 \%$ dw, $C=3.8 \%$ dw (Schneider, 1989a), $\mathrm{C}=5 \% \mathrm{dw}$ (Schneider, 1988) and $\mathrm{C}=1.7 \% \mathrm{dw}$ (Kremer, 1976), respectively.

The wet weight-specific oxygen uptake rates of Baltic Aurelia aurita determined by Thill (1937) were related to carbon by assuming dry weight to be $2 \%$ of wet weight and $C$ $=5 \%$ of dry weight (Schneider, 1988). Finally, the comprehensive study of Cetta et al. (1986) provides 13 regressions between individual respiration rates and individual carbon weights of salps. For each of these regressions two carbon-specific respiration rates, one associated with a carbon weight of $500 \mu \mathrm{g} \mathrm{C}$ ind $^{-1}$ and one referring to a weight of $5000 \mu \mathrm{g}$ ind ${ }^{-1}$, were calculated. These weight values correspond roughly to the lower and upper limits of the regressions.

After all conversions to $\mathrm{mg} \mathrm{O}_{2} \mathrm{gC}^{-1} \mathrm{~d}^{-1}$, the new data were standardized to $15^{\circ} \mathrm{C}$ as described above. For non-gelatinous zooplankton a total of 279 data, representing 1226 measurements, were evaluated. For gelatinous zooplankton 188 data from 1471 measurements were related to carbon as body-mass unit.

\section{RESULTS AND DISCUSSION}

A comparison of the dry weight-specific respiration rates in non-gelatinous and gelatinous zooplankton is given in Figure 1. Values for the non-gelatinous group ranged 

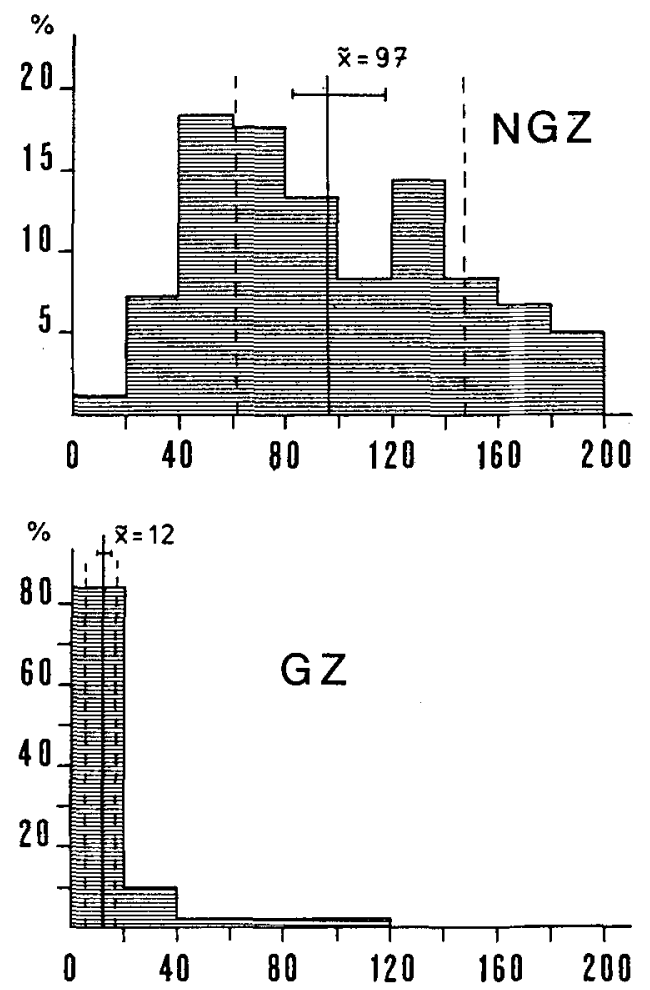

Fig. 1. Frequency distribution of dry weight-specific respiration rates (abscissa: $\mathrm{mg} \mathrm{O}_{2} \mathrm{gdw}^{-1} \mathrm{~d}^{-1}$ ) of non-gelatinous zooplankton (NGZ) and gelatinous zooplankton (GZ). Vertical line denotes median value; horizontal bar indicates $95 \%$ confidence interval of median; and vertical dashes include $50 \%$ of all data (median $\pm 25 \%$ ). These symbols are also used in Figures 2 and 3. Data exceeding $200 \mathrm{mg}$ $\mathrm{O}_{2} \mathrm{gdw}^{-1} \mathrm{~d}^{-1}$ are excluded from the figure

between 10 and $711 \mathrm{mg} \mathrm{O} \mathrm{gdw}^{-1} \mathrm{~d}^{-1}$. However, $90 \%$ of all data are below $200 \mathrm{mg} \mathrm{O}$ $\mathrm{gdw}^{-1} \mathrm{~d}^{-1}$. The median is $97 \mathrm{mg} \mathrm{O}_{2} \mathrm{gdw}^{-1} \mathrm{~d}^{-1}$. By contrast, all data for gelatinous zooplankton are below $120 \mathrm{mg} \mathrm{O}_{2} \mathrm{gdw}^{-1} \mathrm{~d}^{-1}$ and $80 \%$ are between 0 and $20 \mathrm{mg} \mathrm{O}_{2}$ $\mathrm{gdw}^{-1} \mathrm{~d}^{-1}$. A median value of $12 \mathrm{mg} \mathrm{O}_{2} \mathrm{gdw}^{-1} \mathrm{~d}^{-1}$ was calculated for this data set. The median values for both zooplankton groups are significantly different (four-fold table, $\mathrm{Chi}^{2}=4.15, \mathrm{p}<0.05$ ). This result confirms the view that dry weight-specific respiration of gelatinous zooplankton is about one order of magnitude less than that of non-gelatinous zooplankton.

Converting respiration rates to carbon as body mass unit will lead to another figure (Fig. 2). For both zooplankton groups, oxygen uptake rates per $\mathrm{g}$ of carbon are approximately in the same ranges: between 23 and $1034 \mathrm{mg} \mathrm{O}_{2} \mathrm{gC}^{-1} \mathrm{~d}^{-1}$ for non-gelatinous zooplankton and from 13 to $3074 \mathrm{mg} \mathrm{O}_{2} \mathrm{gC}^{-1} \mathrm{~d}^{-1}$ for the gelatinous group. For both types of zooplankton about $90 \%$ of the data are below $500 \mathrm{mg} \mathrm{O}_{2} \mathrm{gC}^{-1} \mathrm{~d}^{-1}$ and $50 \%$ of all data are between 103 and $342 \mathrm{mg} \mathrm{O} \mathrm{gC}^{-1} \mathrm{~d}^{-1}$. The calculated median value for gelatinous 

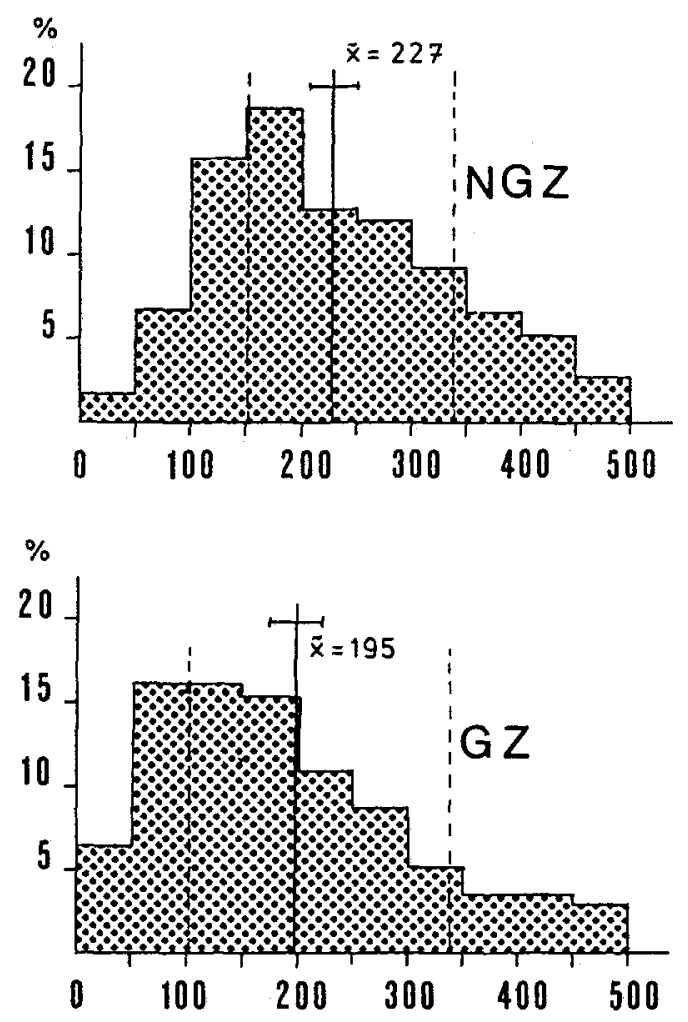

Fig. 2. Frequency distribution of carbon-specific respiration rates of non-gelatinous (NGZ) and gelatinous zooplankton (GZ) (abscissa: $\mathrm{mg} \mathrm{O}_{2} \mathrm{gC}^{-1} \mathrm{~d}^{-1}$ ). Values exceeding $500 \mathrm{mg} \mathrm{O}_{2} \mathrm{gC}^{-1} \mathrm{~d}^{-1}$ are excluded from the figures

zooplankton is slightly lower than that of non-gelatinous zooplankton (195 vs $227 \mathrm{mg} \mathrm{O}$ $\mathrm{gC}^{-1} \mathrm{~d}^{-1}$ ); however, the difference is not significant (four-fold table, $\mathrm{Chi}^{2}=0.0006$ ).

The data set for gelatinous zooplankton shows a broader total range when compared with non-gelatinous organisms, and during calculation of carbon specific respiration, comparatively higher values for salps than for other members of the gelatinous group were recorded. Therefore, the group "Gelatinous zooplankton" was split into "Cnidarians and Ctenophores" on the one hand and "Salps" on the other. A comparison of the carbon-specific oxygen uptake in the two subgroups of gelatinous zooplankton is given in Figure 3. It appears that salps exhibit higher metabolic rates than cnidarians and ctenophores. The median is about twice as high for the former than for the latter. However, due to the broad scattering of data the difference is not significant (four-fold table, $\mathrm{Chi}^{2}=0.102$ ). The same is true when comparing the median values of both subgroups with that of non-gelatinous zooplankton $\left(\mathrm{Chi}^{2}=0.047\right.$ and 0.034 , respectively).

Summing up, when the dry weight-specific respiration rates were converted using carbon as body-mass unit, the oxygen uptake values measured increased approximately 

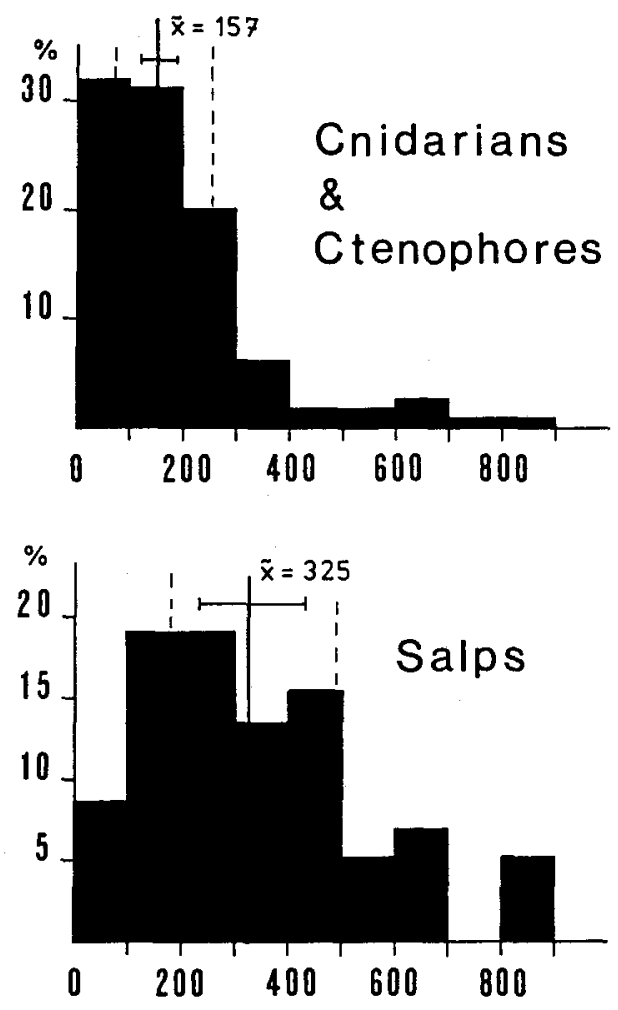

Fig. 3. Frequency distribution of carbon-specific respiration rates of "cnidarians and ctenophores" and "salps". Values exceeding $900 \mathrm{mg} \mathrm{O}_{2} \mathrm{gC}^{-1} \mathrm{~d}^{-1}$ are excluded from the figure

by a factor of two in non-gelatinous zooplankton and by about one order of magnitude in gelatinous zooplankton. These differences are due to the factors between the actual percentage of carbon in dry material and $100 \%$. On the whole, it can be concluded on the basis of measurements using carbon as body-mass unit that gelatinous and non-gelatinous zooplankton respire similar amounts of oxygen. However, there is a tendency for higher rates in salps than in cnidarians and ctenophores.

Generally, such comparisons may be subject to some criticism since different assumptions have to be made which may perhaps lead to more or less significant errors. For example, in this study a constant $Q_{10}$ of two was used for correcting temperature effects on metabolic rates. This rounded value was adopted from Ikeda (1985) who analysed about 700 respiration data, $73 \%$ of the total being from crustaceans. For the gelatinous zooplankton the same $Q_{10}$ was used for the sake of equal treatment of both data sets. However, $Q_{10}$ values within this zooplankton group range from 1 to 7 but were about 3 in most cases (summarized in Larson, $1987 \mathrm{a}$. The extreme value of 25 given in this reference is probably a misprint). Therefore, temperature correction may lead to underor overestimations by an average factor of 1.5. But this applies for rates originally 
measured at temperatures below $15^{\circ} \mathrm{C}$ as well as for those measured at higher temperatures. It can be assumed that most of the differences are averaged out, so that the frequency distribution of data remains fairly unaffected.

Other errors may result from estimating the carbon content of those species for which carbon was not actually measured. This seems less important in non-gelatinous zooplankton since variations are comparatively small (Schneider, 1989a). However, the carbon content of gelatinous species can vary over one order of magnitude, so that application of an average value to a distinct species may be rather erroneous. Fortunately, such "blind" assumptions were only necessary in a few cases. However, most carbon values could be drawn from other literature sources studying the species to which the carbon value must be applied.

Since the publication of Biggs (1977) contributes a substantial part of total gelatinous zooplankton data $(36 \%)$ it should not be overlooked that equalizing protein content with carbon content can be taken as a rule of thumb only. The contribution of proteins to total organic matter may exceed $60 \%$, whereas carbon may be below one half of organic matter (cf. Raymont, 1983), and vice versa. Generally, this depends upon the total biochemical composition. For example, low amounts of lipids will lead to a high contribution of proteins and a smaller one of carbon to total organic matter, whereas the opposite is true when lipids are plenty. However, the difference between both components will never be large.

On the whole, these different kinds of errors appear too small to distort the overall message that respiration of non-gelatinous and gelatinous zooplankton falls into the same range if carbon serves as body-mass unit.

With respect to body weight, this may be an unexpected result since most gelatinous species are considerably larger than non-gelatinous zooplankton. Experimental determinations of the allometric exponent relating metabolic rates to individual body weight according to the well known equation $\mathrm{M}=\mathrm{a} \mathrm{W}$, revealed $\mathrm{b}$-values to range between 0.3 and 1.6 in gelatinous zooplankton. However, most values were close to unity (Table 4). This indicates no decrease of weight-specific respiration rates with increasing body weight which may be a result of specific growth conditions (Krüger, 1968). Moreover, Phillipson (1981) found b-values to be close to 0.9 in a large data set for multicellular ectotherms, and therefore the differences in weight-specific respiration between e.g. smaller crustaceans and large medusae are minor and are buried by variability due to other agents.

Such variability may emerge from the animals' response to starvation. In most studies both types of zooplankton were incubated without food, and experiments started either as soon as possible after sampling or after a period (usually a few hours) of starvation. It is well-known that metabolic rates decline in the absence of food. Gyllenberg \& Greve (1979) demonstrated that starving Pleurobrachia pileus lost one half of their respiratory activity within one day, and reached a low but more or less constant level of oxygen uptake in the following days. Similar observations are reported for representatives of non-gelatinous zooplankton (cf. Ikeda \& Skjoldal, 1980). Therefore, most incubation periods overlap with the time-span of maximal decline of respiration. Since it can be assumed that the degree of metabolic decline with time varies between species, and may, moreover, depend upon the food regime in the sea prior to sampling, this may influence experimental results. 
Table 4. Compilation of $\mathrm{b}$-values relating individual respiration to individual weight. WM = weighted mean; $n=$ number of $b$-values determined; $n^{*}=$ number of measurements

\begin{tabular}{|llrrrl|}
\hline Zooplankton & Range & WM & $\mathrm{n}$ & $\mathrm{n}^{*}$ & Source \\
\hline Scyphomedusae & $0.91-0.99$ & 0.96 & 3 & 72 & Krüger (1967) \\
& $0.92-1.04$ & 0.95 & 4 & 67 & Larson (1987a) \\
& 0.94 & & 1 & 18 & Schneider (1989c) * \\
Hydromedusae & 0.81 & & 1 & 14 & Biggs (1977) \\
& $0.71-1.40$ & 0.99 & 13 & 271 & Larson (1987a) \\
Siphonophores & $0.75-1.61$ & 1.15 & 8 & 163 & Biggs (1977) \\
Ctenophores & 1.28 & & 1 & 10 & Biggs (1977) \\
& $0.96-1.28$ & 1.03 & 6 & 144 & Kremer (1977) \\
Salps & $0.64-1.12$ & 0.88 & 4 & 141 & Kremer et al. (1986) \\
& $1.30-1.61$ & 1.37 & 2 & 34 & Biggs (1977) \\
& 0.74 & 1 & 16 & Ikeda \& Mitchell (1982) \\
Total range: & $0.26-1.63$ & 0.97 & 13 & 274 & Cetta et al. (1986) \\
Total weighted mean: & $0.26-1.63$ & & & & \\
Arithmetic mean \pm SD: & $1.00 \pm 0.26, \mathrm{n}=57$ & & & \\
95\% conf. interval: & $0.93-1.07$ & & & & \\
* Calculated from data in Thill (1937) and Kerstan (1977) & & & \\
\hline
\end{tabular}

Furthermore, we have to take into account the existence of lethargic and more active species within a taxonomic group. For salps, Cetta et al. (1986) showed that active species, pulsing at rates between 60 and $100 \mathrm{~min}^{-1}$, exhibit a twofold higher respiration rate than those species pulsing only between 23 to 72 times per minute. Another example is reported by Youngbluth et al. (1988) where the immobile or slow swimming midwater ctenophore Bathocyroe fosteri respires only one third the value of the co-occurring but more active Ocyropsis sp. which probably has only a slightly higher carbon content.

However, variability may also occur for reasons unknown to us. Respiration rates of certain ctenophores were between two and six times higher according to measurements by Biggs (1977) when compared with those obtained by Kremer et al. (1986) for the same species. No suitable explanations can be given for these differences (Kremer et al. 1986).

As mentioned above, salps tend to exhibit higher respiration rates than cnidarians and ctenophores, and one might expect salps to be rather active gelatinous individuals requiring more oxygen for muscle contractions and locomotion than the more lethargic appearing medusae. Various experiments, however, revealed swimming to be rather efficient in salps. Specific effort which has to be exerted for locomotion is low, and similar or less than in medusae (Bone \& Trueman, 1983, 1984; Trueman et al., 1984; Larson, 1987b; Reinke, 1987; Madin, 1990). Possibly, formation of food webs may lead to increased respiration by enhanced drag forces, but this is speculative in the context of the data presented here.

On the other hand, it is difficult to obtain independent support for the suggestion of generally higher rates in salps. According to Cetta et al. (1986), carbon turnover rates are high, ranging between 10 and $40 \% \mathrm{~d}^{-1}$ (extreme: $100 \% \mathrm{C} \mathrm{d}^{-1}$ ) and are therefore higher 
than turnover rates estimated for hydro- and scyphomedusae (Larson, 1987 a). This is also true after corrections for different experimental temperatures.

Alternatively, carbon turnover rates estimated from filtration and ingestion studies were between 25 and more than $100 \%$ body-C $\mathrm{d}^{-1}$ (Mullin, 1983; Andersen, 1985; Deibel, 1985), coinciding with the high turnover rates obtained from oxygen consumption measurements. The problem remains unresolved here. It cannot be excluded that the higher respiration rates of salps are an artifact due to natural variability, errors mentioned above and the comparatively low numbers of data. Further observations are needed for verification or falsification.

To sum up, the data compilation presented here suggests carbon-specific respiration rates to be similar in gelatinous and non-gelatinous zooplankton. Therefore, if carbon serves as body mass unit, cnidarians, ctenophores and salps cannot be regarded as being metabolically less active. Equal carbon biomass stocks of both types of zooplankton in the sea require similar amounts of oxygen and release similar amounts of ammonia via excretion (Schneider, 1990). Low metabolic rates of gelatinous zooplankton occur only on a per individual basis, and by comparing those rates with that of non-gelatinous organisms of the same volume. This results from the low absolute amount of organic matter in the former but not by any quality of the organic matter itself. Therefore, since the dry weight / carbon ratios are rather different between the two major groups of zooplankton as well as between the members of the gelatinous and non-gelatinous taxa, it is recommended that weight-specific metabolic rates should be expressed on a carbon basis for proper comparisons or on any other basis characterizing organic content (e.g. nitrogen or proteins).

Finally, the reader may allow some remarks with an evolutionary view. Gelatinous body composition seems to be an old and successful strategy. First medusan-like fossils are recorded from the Ediacara fauna of approximately 600 million years ago (Glaessner, 1962; Cloud \& Glaessner, 1982). During those early days of multicellular organization, environmental conditions were harsh. We know that, at best, oxygen made up only one tenth of the present value. It can be assumed that production in the old oceans was much less and spatial heterogeneity considerably larger than today. Gelatinous organization was probably of adaptational value to these conditions since small amounts of organic matter required comparatively little oxygen but allowed increase of body size with large surfaces for diffusion of oxygen and for catching of prey, especially in predominantly disc-shaped medusae or well-structured sea-feather like sessile cnidarians (e.g. Charniodiscus spp.). We do not know anything about the food of the early medusae. Possibly, interspecific predation may have played a role. However, it may be assumed that feeding on unicellular microplankton dominated in a sea fairly devoid of metazoans, and was perhaps carried out in the way displayed by present-day Aurelia aurita medusae (Southward, 1955).

Be the latter as it may, medusae were probably the first multicellular animals to enter the pelagic realm, remaining there for over half a billion years. Probably, gelatinous organization was a key to this step, and it is an interesting case of convergence that some of the crustaceans that live in oxygen-poor deeper water layers also exhibit a fairly gelatinous body composition (Childress \& Nygaard, 1974; Flint et al., 1991). 


\section{LITERATURE CITED}

Andersen, V., 1985. Filtration and ingestion rates of Salpa fusiformis Cuvier (Tunicata: Thaliacea): Effects of size, individual weight and algal concentration. - J. exp. mar. Biol. Ecol. 87, 13-29.

Biggs, D. C., 1977. Respiration and ammonium excretion by open ocean gelatinous zooplankton. Limnol. Oceanogr. 22, 108-117.

Biggs, D. C., 1982. Zooplankton excretion and $\mathrm{NH}_{4}^{+}$-cycling in near surface waters of the Southern Ocean. I. Ross Sea, austral summer 1977-1978. - Polar Biol. 1, 55-67.

Bone, Q. \& Trueman, E. R., 1983. Jet propulsion in salps (Tunicata: Thaliacea). - J. Zool. 201, 481-506.

Bone, Q. \& Trueman, E. R., 1984. Jet propulsion in Doliolum (Tunicata: Thaliacea). - J. exp. mar. Biol. Ecol. 76, 105-118.

Cetta, C. M., Madin, L. P. \& Kremer, P., 1986. Respiration and excretion by oceanic salps. - Mar. Biol. $91,529-537$.

Childress, J. J. \& Nygaard, M., 1974. Chemical composition and buoyancy of midwater crustaceans as a function of occurrence off Southern California. - Mar. Biol. 27, 225-238.

Cloud, P. \& Glaessner, M. F., 1982. The Ediacarian period and system: Metazoa inherit the earth. Science N.Y. 217, 783-792.

Deibel, D., 1985. Clearance rates of the salp Thalia democratica fed naturally occurring particles. Mar. Biol. 86, 47-54.

Flint, M. V., Drits, A.V. \& Pasternak, A.F., 1991. Characteristic features of body composition and metabolism in some interzonal copepods. - Mar. Biol. 111, 199-205.

Glaessner, M. F., 1962. Pre-Cambrian fossils. - Biol. Rev. 37, 467-494.

Gyllenberg, G. \& Greve, W., 1979. Studies on oxygen uptake in ctenophores. - Annls. zool. fenn. 16, $44-49$.

Härdstedt-Roméo, M., 1982. Some aspects of the chemical composition of plankton from the NorthWestern Mediterranean Sea. - Mar. Biol. 70, 229-236.

Hirota, J., 1972. Laboratory culture and metabolism of the planktonic ctenophore Pleurobrachia bachei A. Agassiz. In: Biological oceanography of the northerr North Pacific Ocean. Ed. by A. Y. Takenouti. Idemitsu Shoten, Tokyo, 465-484.

Ikeda, T., 1974. Nutritional ecology of marine zooplankton. - Mem. Fac. Fish. Hokkaido Univ. 22, $1-97$.

Ikeda, T., 1985. Metabolic rates of epipelagic marine zooplankton as a function of body mass and temperature. - Mar. Biol. 85, 1-11.

Ikeda, T. \& Bruce, B., 1986. Metabolic activity and elemental composition of krill and other zooplankton from Prydz Bay, Antarctica, during early summer (November-December). - Mar. Biol. 92, 545-555.

Ikeda, T. \& Mitchell, A.W., 1982. Oxygen uptake, ammonia excretion and phosphate excretion by krill and other antarctic zooplankton in relation to their body size and chemical composition. Mar. Biol. 71, 283-298.

Ikeda, T. \& Skjoldal, H.R., 1980. The effect of laboratory conditions on the extrapolation of experimental measurements to the ecology of marine zooplankton. VI. Changes in physiological activities and biochemical components of Acetes sibogae australis and Acartia australis after capture. - Mar. Biol. 58, 285-293.

Ikeda, T. \& Skjoldal, H. R., 1989. Metabolism and elemental composition of zooplankton from the Barents Sea during early Arctic summer. - Mar. Biol. 100, 173-183.

Kerstan, M., 1977. Untersuchungen zur Nahrungsökologie von Aurelia aurita Lam. Diss., Univ. Kiel, $95 \mathrm{pp}$.

Kremer, P., 1976. Excretion and body composition of the ctenophore Mnemiopsis leidyi (A. Agassiz): Comparisons and consequences. In: Proceedings of the $10^{\text {th }}$ European symposium on marine biology. Ed. by G. Persoone \& F. Jaspers. Universa Press, Wetteren, 2, 351-362.

Kremer, P., 1977. Respiration and excretion by the ctenophore Mnemiopsis leidyi. - Mar. Biol. 44, 43-50.

Kremer, P., 1982. Effect of food availability on the metabolism of the ctenophore Mnemiopsis mccradyi. - Mar. Biol. 71, 149-156. 
Kremer, P., Canino, M.F. \& Gilmer, R.W., 1986. Metabolism of epipelagic tropical ctenophores. Mar. Biol. 90, 403-412.

Krüger, F., 1968. Stoffwechsel und Wachstum bei Scyphomedusen. - Helgoländer wiss. Meeresunters. $18,367-383$.

Larson, R. J., 1986. Water content, organic content, and carbon and nitrogen composition of medusae from the Northeast Pacific. - J. exp. mar. Biol. Ecol. 99, 107-120.

Larson, R. J., 1987a. Respiration and carbon turnover rates of medusae from the NE Pacific. - Comp. Biochem. Physiol. 87 A, 93-100.

Larson, R.J., 1987b. Costs of transport for the scyphomedusa Stomolophus meleagris L. Agassiz. Can. J. Zool. 65, 2690-2695.

Madin, L. P., 1990. Aspects of jet propulsion in salps. - Can. J. Zool. 68, 765-777.

Menzel, D. W. \& Ryther, J. H., 1961. Zooplankton in the Sargasso Sea off Bermuda and its relation to organic production. - J. Cons. perm. int. Explor. Mer 26, 250-258.

Mullin, M. M., 1983. In situ measurements of filtering rates of the salp Thalia democratica, on phytoplankton and bacteria. - J. Plankt. Res. 5, 279-288.

Omori, M., 1969. Weight and chemical composition of some important oceanic zooplankton in the North Pacific Ocean. - Mar. Biol. 3, 4-10.

Omori, M. \& Ikeda, T., 1984. Methods in marine zooplankton ecology. Wiley, New York, $332 \mathrm{pp}$.

Phillipson, J., 1981. Bioenergetic options and phylogeny. In: Physiological ecology: an evolutionary approach to ressource use. Ed. by C. P. Towsend \& P. Calow. Blackwell, London, 20-45.

Platt, T., Brown, V. \& Irwin, B., 1969. Caloric and carbon equivalents of zooplankton biomass. - J. Fish. Res. Bd Can. 26, 2345-2349.

Raymont, J.E. G., 1983. Plankton and productivity in the oceans. II. Zooplankton. Pergamon Press, Oxford, $824 \mathrm{pp}$.

Reinke, M., 1987. Zur Nahrungs- und Bewegungsphysiologie von Salpa thompsoni und Salpa fusiformis. - Ber. Polarf. 36, 1-86.

Schneider, G., 1988. Chemische Zusammensetzung und Biomasseparameter der Ohrenqualle Aurelia aurita. - Helgoländer Meeresunters. 42, 319-327.

Schneider, G., 1989a. Carbon and nitrogen content of marine zooplankton dry material; a short review. - Plankt. Newsl. 11, 4-7.

Schneider, G., 1989b. Estimation of food demands of Aurelia aurita medusae populations in the Kiel Bight, Western Baltic. - Ophelia 31, 17-27.

Schneider, G., 1990. A comparison of carbon based ammonia excretion rates between gelatinous and non-gelatinous zooplankton: Implications and consequences. - Mar. Biol. 106, 219-225.

Schneider, G. \& Lenz, J., 1991. Zooplankton community metabolism in the upper $200 \mathrm{~m}$ of the central Red Sea and the Gulf of Aden - Mar. Ecol. Prog. Ser. 77, 301-306.

Shushkina, E. A. \& Pavlova, Ye. P., 1973. Metabolism rate and production of zooplankton in the equatorial Pacific. - Oceanology, Wash. 13, 278-284.

Southward, A.J., 1955. Observations on the ciliary currents of the jellyfish Aurelia aurita L. - J. mar. biol. Ass. U. K. 34, 201-216.

Thill, H., 1937. Beiträge zur Kenntnis der Aurelia aurita (L.). - Z. wiss. Zool. 150, 51-97.

Trueman, E.R., Bone, Q. \& Braconnot, J.-C., 1984. Oxygen consumption in swimming salps (Tunicata: Thaliacea). - J. exp. Biol. 110, 323-327.

Weisse, T., 1985. Die Biomasse und Stoffwechselaktivität des Mikro- und Mesozooplanktons in der Ostsee. - Ber, Inst. Meeresk. Kiel 144, 127 pp.

Youngbluth, M. J., Kremer, P., Bailey, T. G. \& Jacoby, C. A., 1988. Chemical composition, metabolic rates and feeding behavior of the midwater ctenophore Bathocyroe fosteri. - Mar. Biol. 98, 87-94. 